\title{
Removal of methylene blue (MB) by Bimetallic-Metal organic Framework
}

\author{
Naser Al Amery ${ }^{1, *}$, Hussein Rasool Abid ${ }^{1,2,3}$, Shaobin Wang ${ }^{4}$, and Shaomin Liu ${ }^{1}$ (1) \\ ${ }^{1}$ Chemical Engineering, WA School of Mines: Minerals, Energy and Chemical Engineering, Curtin University, Australia \\ ${ }^{2}$ Environmental Department, Applied Medical Science, University of Karbala, Iraq \\ ${ }^{3}$ School of Engineering, Edith Cowan University, Australia \\ ${ }^{4}$ School of Chemical Engineering, University of Adelaide, Australia
}

\begin{abstract}
In this study, three improved versions of UiO-66 were synthesised successfully: Different ratios of $\mathrm{Ca}^{+2} / \mathrm{Zr}^{+4}$ were used to synthesize $\mathrm{UiO}-66, \mathrm{UiO}-66-10 \% \mathrm{Ca}$ and $\mathrm{UiO}-66-30 \% \mathrm{Ca}$. These MOFs were used in batch adsorption experiments to remove different concentration of methylene blue (MB) from wastewater. When the concentration of $\mathrm{MB}$ was $50 \mathrm{ppm}$, UiO66-10\% Ca had the highest affinity toward MB therefore it exhibited adsorption capacity of $50.25 \mathrm{mg} \cdot \mathrm{g}^{-1}$. Furthermore, the MB adsorption capacity was $22.75 \mathrm{mg} . \mathrm{g}^{-1}$ and $14.84 \mathrm{mg} \cdot \mathrm{g}^{-1}$ in $\mathrm{UiO}-66-30 \% \mathrm{Ca}$ and $\mathrm{UiO}-66$ respectively. For equilibrium study, Langmuir and Freundlich models were used to fit the experimental data. Freundlich model was the best to describe the adsorption equilibrium of MO. A kinetics study was described by pseudo first-order, pseudo second-order and intraparticle diffusion models. Pseudo second-order model demonstrated the best fitting to the experimental data. The MOFs used in this study are suggested to be attractive adsorbents to remove dyes from wastewater.
\end{abstract}

Key words: MOFs, Bimetallic, UiO-66, methylene blue, adsorption

\section{INTRODUCTION}

Dyes exist where there is civilisation. They are used to colour products, and employed in various industries, such as the food, paper, carpet, rubber, plastic, cosmetic, acrylic, wool, nylon, silk and textile industry [1-3].

Cationic methylene blue MB (tetramethylthionine chloride) is a basic thiazine dye as shown in Figure 1 [4]. As a basic dye, MB is not strongly hazardous, but may cause some harmful effects on humans and aquatic lives. It is also resistant to biological degradation [5].

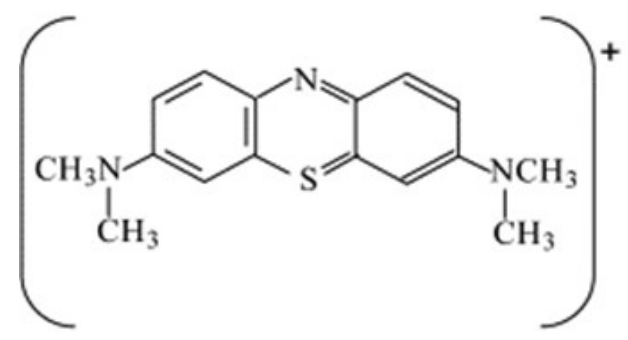

Fig. 1. Chemical structure of $\mathrm{MB}[1]$.

Water is a precious resource for all living creatures on earth. A significant environmental challenge is the removal of dye pollutants from fabric and textile wastewater [6]. Use of dyes to colour products consumes significant volumes of water; consequently, a substantial amount of coloured wastewater can be generated [7]. Many approaches to dye removal have been proposed to treat the industrial wastewater $[8,9]$. The techniques are classified into three main types: physical, chemical and biological treatments. These techniques include coagulation, membrane, separation process, adsorption process, filtration, softening , reverse osmosis, electrochemical processes, chemical oxidation, and aerobic and anaerobic microbial degradation [10].

The adsorption process is the simplest technique for dye removal due to its low cost, easy availability, simplicity of design, high efficiency, ease of operation $[11,12]$. While activated carbon is presently believed to be the most operative adsorbent, its high cost means its production and regeneration remain uneconomical $[13,14]$. This limitations of using activated carbons have led researchers to seek low-priced dye sorbents, such as coal, fly-ash, silica gel, wool waste, agricultural waste, wood waste, and clay materials [11, 15]. In recent years, research and development in the field of design and synthesis of MOFs has led to a rapid growth in practical and conceptual developments [16-21]. An extensive class of crystalline materials has become available because of metal organic framework (MOF) chemistry, which has superior characteristics such as high stability, tuneable metrics, organic functionality and porosity [16].

Its exceptional porousness means that MOFs have potentially numerous applications; their demonstrated applications in gas storage, separations, catalysis, energy

$\begin{array}{ll}\text { Received } & \text { : October 01, 2020 } \\ \text { Revised } & \text { : November 09, 2020 } \\ \text { Accepted } & \text { : November 16, 2020 }\end{array}$


technology fuel cells, supercapacitors and catalytic conversions has made them objects of intensive study, industrial-scale production and application [22-25].

The unique characteristics of MOF-type substances that make them the focus of much worldwide research are their pore geometry and high porosity $[26,27]$, their central metals $[28,29]$, open metal sites $[30,31]$, functionalised linkers $[32,33]$ and their loading of active species [34, 35]. All these characteristics have been scientifically employed to successfully improve interactions between the sorbates and MOFs. Specifically, these characteristics distinguish MOFs from other porous material in the field of adsorption processes for the effective removal of hazardous compounds [36]. Accordingly, MOFs are superior adsorbents because of their various host-guest interactions, acid-base [37, 38], $\pi$-complexation [39], H-bonding [40, 41] and coordination with open metal sites $[31,36]$. The pore size has a prime effect on the adsorption capacity of MOFs therefore exceptionally high dye uptake was demonstrated by mesoporous MOFs [42]. Very few studies was made based on bimetallic MOF [43]. UiO-66 has attractive characteristics as an adsorbent to toxic chemicals from wastewater because it has a higher hydrothermal stability among other MOFs [44]. Bimetallic-UiO-66 was recently used to significantly adsorb anionic dyes [45].

In this study, based on batch adsorption experiments, $\mathrm{UiO}-66$ and $\mathrm{UiO}-66-\mathrm{Ca}$ samples were used as sorbents to remove $\mathrm{MB}$ from an aqueous solution. Equilibrium and kinetic adsorption models were used to represent the experimental data. The equilibrium study was undertaken using Langmuir and Freundlich isotherms. The kinetics study was conducted using pseudo first-order and pseudo second-order models as well as intraparticle diffusion.

\section{MATERIALS AND METHODS}

\subsection{Synthesis and Activation}

All chemicals were supplied by Sigma-Aldrich (Australia) without further purifications.

UiO-66 was synthesised successfully using a scaled-up procedure of a previously reported method [46]. Specifically, $2.27 \mathrm{mmol}$ of $\mathrm{ZrCl}_{4}$ and $2.27 \mathrm{mmol}$ 1,4-benzenedicarboxylic acid (BDC) were mixed with $405.38 \mathrm{mmol}$ of $\mathrm{N}, \mathrm{N}$-dimethylformamide (DMF) in an autoclave and heated in a preheating oven at $393 \mathrm{~K}$ for $24 \mathrm{~h}$. The produced UiO-66 was immersed in chloroform for 5 days to remove unreacted precursors. Then, the crystalline product was filtered and dried under vacuum at $463 \mathrm{~K}$ for $48 \mathrm{~h}$.

UiO-66-10\%Ca was synthesised by mixing $\mathrm{ZrCl}_{4}$ (1.5 g) with BDC $(1.1 \mathrm{~g})$ in $73 \mathrm{~mL}$ of DMF. After mixing for $15 \mathrm{~min}, 0.15 \mathrm{~g}$ of $\mathrm{Ca}(\mathrm{NO} 3)_{2} .4 \mathrm{H}_{2} \mathrm{O}$ was added and followed by the addition of $2 \mathrm{~mL}$ of $\mathrm{H}_{2} \mathrm{O}$ to the mixture. The solution is mixed for approximately $30 \mathrm{~min}$; then transferred into a $125-\mathrm{mL}$ Teflon-lined autoclave, which is tightly sealed and placed in a preheated oven at $132{ }^{\circ} \mathrm{C}$ for $1 \mathrm{~d}$.

$\mathrm{UiO}-66-30 \% \mathrm{Ca}$ was synthesised by mixing $\mathrm{ZrCl}_{4}$ (1.5 g, $6.44 \mathrm{mmol})$ with BDC $(1.3 \mathrm{~g}, 7.82 \mathrm{mmol})$ in $70 \mathrm{~mL}$ of DMF. The solution was mixed for $30 \mathrm{~min}$, then $\mathrm{Ca}\left(\mathrm{NO}_{3}\right)_{2} \cdot 4 \mathrm{H}_{2} \mathrm{O}$ (0.45 g, $2.86 \mathrm{mmol}$, 99\%; Sigma-Aldrich) was added to the mixture. After that, $5 \mathrm{~mL}$ of deionised water was added into the mixture. Eventually, the mixture was transferred to a Teflon-lined autoclave which was tightly sealed and moved into a preheating oven at $430 \mathrm{~K}$. The products were then filtered, dried and immersed in absolute methanol $(100 \%$, Sigma-Aldrich) for $5 \mathrm{~d}$, after that it was dried and heated under vacuum at $473 \mathrm{~K}$ overnight before use as adsorbents.

\subsection{Characterisation}

The thermal stability of $\mathrm{UiO}-66, \mathrm{UiO} 66-10 \% \mathrm{Ca}$ and UiO66-30\% Ca were assessed by a thermogravimetric analysis (TGA) instrument (TGA/DSC1 STARe system; Mettler-Toledo). The samples were loaded into a pan and heated to $1173 \mathrm{~K}$ at a rate of $5 \mathrm{~K} / \mathrm{min}$. The air flow rate was maintained at $50 \mathrm{~mL} / \mathrm{min}$. FTIR spectra (Spectrum 100 FT-IR spectrometer, PerkinElmer, Waltham, USA) were obtained to assess the stability of the functional groups on the organic ligands. The spectra were scanned from 600 to $4000 \mathrm{~cm}^{-1}$ with a resolution of $4 \mathrm{~cm}^{-1}$ using an attenuated total reflectance technique. X-ray powder diffraction and patterns were obtained with an X-ray diffractometer (D8 Advance, Bruker AXS) using $\mathrm{Cu} \mathrm{Ka}$ radiation $(\lambda=1.5406 \AA)$ with accelerating voltage and current of $40 \mathrm{kV}$ and $40 \mathrm{~mA}$ respectively. Autosorb-1(Quantachrome, instruments) was used to determine $\mathrm{N}_{2}$ adsorption/ desorption isotherms as well as the pore size and surface area of the MOFs. The samples were initially evacuated at $473 \mathrm{~K}$ for $24 \mathrm{~h}$. Then, the sample was analysed to determine surface area, pore size and pore volume.

\subsection{Adsorption Study}

An aqueous stock solution of $\mathrm{MB}(1000 \mathrm{ppm})$ was prepared by dissolving $\mathrm{MB} \quad\left(\mathrm{C}_{16} \mathrm{H}_{18} \mathrm{ClN}_{3} \mathrm{~S}, \geq 95 \%\right.$, Sigma-Aldrich) in deionised water. Aqueous solutions with different concentrations of $\mathrm{MB}$ (5-100 ppm) were prepared by successive dilution of the stock solution with water. After obtaining the UV spectra of the solutions with a spectrophotometer (UV spectrophotometer), the MB concentrations were determined using absorbance at $668 \mathrm{~nm}$ wavelength of the solutions. A calibration curve was obtained from the spectra of the standard solutions (5-100 ppm).

Prior to adsorption, the adsorbents were dried overnight under vacuum at $373 \mathrm{~K}$. Several glass containers were cleaned, dried and filled to $20 \mathrm{~mL}$ with $\mathrm{MB}$ of different concentrations ranging from 5 to $50 \mathrm{ppm}$. An exact amount of the MOF adsorbent $(20 \mathrm{mg})$ was then put in each container.

The dye solutions containing the adsorbents were mixed well with a magnetic stirrer and maintained for a period from $5 \mathrm{~min}$ to $24 \mathrm{~h}$ at $298 \mathrm{~K}$. Samples for analysis were collected by a syringe filter at different sampling intervals. UV spectrometer was used to investigate the dye content in the supernatant.

Adsorbed amounts of MB by the Zr-MOFs at each time interval of time, the equilibrium and percentage removal of $\mathrm{MB}$ were computed according to the following equations:

$$
q_{t}=\left(C_{0}-C_{t}\right) \frac{V}{m}
$$




$$
\begin{aligned}
q_{e} & =\left(C_{0}-C_{e}\right) \frac{V}{m} \\
R \% & =\frac{\left(C_{0}-C_{t}\right)}{C_{0}} X 100
\end{aligned}
$$

Where:

qt : the amount of $\mathrm{MB}$ adsorbed per unit weight of MOF at any time $\mathrm{t}(\mathrm{mg} / \mathrm{g})$

qe : the amount of $\mathrm{MB}$ adsorbed per unit weight of $\mathrm{MOF}$ at equilibrium $(\mathrm{mg} / \mathrm{g})$

$\mathrm{C}_{0}$ : the initial concentration of the $\mathrm{MB}$ solution at time zero $(\mathrm{mg} / \mathrm{L})$

$\mathrm{C}_{\mathrm{t}}$ : the concentration of the MB solution at time $\mathrm{t}(\mathrm{mg} / \mathrm{L})$

$\mathrm{C}_{e}$ : the concentration of the $\mathrm{MB}$ solution at equilibrium $(\mathrm{mg} / \mathrm{L})$

$\mathrm{V}$ : volume of the $\mathrm{MB}$ solution in batch adsorption process (L)

$\mathrm{R} \%$ : percentage removal of $\mathrm{MB}$ [5]

$\mathrm{m}$ : Zr-MOF mass used in adsorption batch process $(\mathrm{g})$ $[1,5,47]$.

Adsorption mechanism and rate of diffusion were estimated using three kinetic models: pseudo first-order, pseudo second-order [48-50] and intraparticle diffusion model $[51,52]$. The adsorbents' adsorption behaviours were simulated using the Freundlich and Langmuir adsorption isotherms $[48-50,53]$.

Kinetics study: Adsorption mechanism and rate of diffusion were estimated using three kinetic models: pseudo first-order, pseudo second-order [48-50] and intraparticle diffusion model $[51,52]$.

The nonlinear form of the Lagergren pseudo first-order kinetic equation can be written as follows $[54,55]$ :

$$
\frac{d q}{d t}=k_{1}\left(q_{e}-q_{t}\right)
$$

The linear form of the pseudo first-order kinetic equation can be expressed as follows:

$$
\ln \left(q_{e}-q_{t}\right)=\ln \left(q_{e}\right)-k_{1} t
$$

The nonlinear form of the pseudo second-order kinetic equation can be written as follows [56]:

$$
\frac{d q}{d t}=k_{2}\left(q_{e}-q_{t}\right)^{2}
$$

The linear form of the pseudo second-order kinetic equation can be written as follows:

$$
\frac{t}{q_{t}}=\frac{1}{k_{2} q_{e}^{2}}+\frac{1}{q_{e}} t
$$

Where:

qe : the amount of $\mathrm{MB}$ adsorbed per unit weight of MOF at equilibrium $(\mathrm{mg} / \mathrm{g})$

qt : the amount of MB adsorbed per unit weight of MOF at any time $\mathrm{t}(\mathrm{mg} / \mathrm{g})$

$\mathrm{k} 1$ : pseudo first-order rate constant $\left(\mathrm{min}^{-1}\right)$ $\mathrm{t} \quad$ : time $(\mathrm{min})$

$\mathrm{k}_{2}$ : pseudo second-order rate constant ( $\left.\mathrm{g} / \mathrm{mg} \mathrm{min}\right)$.

A linear plot of the pseudo first-order model (ln $\left[\mathrm{q}_{\mathrm{e}}-\mathrm{q}_{\mathrm{t}}\right]$ ) against time provides the values for the kinetics sorption parameters, such as rate constant $\left(\mathrm{k}_{1}\right)$, equilibrium adsorption capacity $\left(\mathrm{q}_{\mathrm{e}}\right)$ and the linear regression coefficient $\left(\mathrm{R}^{2}\right)$. Likewise, a linear plot of the pseudo second-order model $\left(\mathrm{t} / \mathrm{q}_{\mathrm{t}}\right)$ against time also provides the rate constant $\left(\mathrm{k}_{2}\right)$, equilibrium adsorption capacity $\left(\mathrm{q}_{\mathrm{e}}\right)$ and the linear regression coefficient $\left(\mathrm{R}^{2}\right)$.

As a result of the limitations of the pseudo first-order and pseudo second-order kinetic equations, the lack of an identified adsorption mechanism and the rate-limiting steps in the adsorption process, Weber and Morris established intraparticle diffusion model [117]. In general, the migration of sorbate molecules in bulk to the surface of a solid sorbent by intraparticle diffusion process is what controls the rate of most liquid/solid sorption systems. The analysis using Weber and Morris's intraparticle diffusion model is as follows [51, 52]:

$$
q_{t}=k_{p} t^{1 / 2}+C
$$

Where:

qt : the amount of $\mathrm{MB}$ adsorbed per unit weight of $\mathrm{MOF}$ at any time $\mathrm{t}(\mathrm{mg} / \mathrm{g})$

$\mathrm{kp}$ : intraparticle diffusion rate constant $\left(\mathrm{mg} / \mathrm{g} \mathrm{\operatorname {min } ^ { 0 . 5 } )}\right.$

$\mathrm{t}$ : time (min)

C : constant represents the surface adsorption [57-59].

Equilibrium study: The adsorbents' adsorption behaviours were simulated using the Freundlich and Langmuir adsorption isotherms [48-50, 53].

The nonlinear form of the Langmuir isotherm can be expressed as:

$$
q_{e}=\frac{q_{m} k_{L} C_{e}}{\left(1+k_{L} C_{e}\right)}
$$

while the linear form can be written as [60]:

$$
\frac{C_{e}}{q_{e}}=\frac{1}{q_{m}} C_{e}+\frac{1}{k_{L} q_{m}}
$$

Where:

qm : Langmuir maximum loading capacity $(\mathrm{mg} / \mathrm{g})$

$\mathrm{k}_{\mathrm{L}}$ : Langmuir constant related to the energy of adsorp tion and affinity of binding sites $(\mathrm{L} / \mathrm{mg})$ [61]

$\mathrm{C}_{\mathrm{e}}$ : Equilibrium concentration of dye in solution (mg/L)

qe : Amount of dye adsorbed at equilibrium per unit mass of sorbent $(\mathrm{mg} / \mathrm{g})$.

The equilibrium experimental data were fitted using the linear form of the Langmuir isotherm equation (Equation 9). Specifically, the Langmuir parameters $q_{m}, K_{L}$, and $R^{2}$ were obtained from the plot of $\left(\mathrm{C}_{\mathrm{e}} / \mathrm{q}_{\mathrm{e}}\right)$ against $\mathrm{C}_{\mathrm{e}}$.

The dimensionless constant separation factor, $\mathrm{R}_{\mathrm{L}}$, is vital to the Langmuir isotherm, and can be found in the following equation [62-65]:

$$
R_{L}=\frac{1}{\left(1+k_{L} C_{0}\right)}
$$


Where $\mathrm{C}_{0}$ is the initial concentration of adsorbate $(\mathrm{mg} / \mathrm{L})$ and $\mathrm{K}_{\mathrm{L}}(\mathrm{L} / \mathrm{mg})$ is the Langmuir constant.

The shape of the isotherm depends on $\mathrm{R}_{\mathrm{L}}$, because this factor indicates the adsorption process as:

$$
\begin{aligned}
& \text { Unfavourable }\left(\mathrm{R}_{\mathrm{L}}>1\right) \\
& \text { Linear }\left(\mathrm{R}_{\mathrm{L}}=1\right) \\
& \text { Favourable }\left(0<\mathrm{R}_{\mathrm{L}}<1\right) \\
& \text { Irreversible }\left(\mathrm{R}_{\mathrm{L}}=0\right) .
\end{aligned}
$$

The nonlinear form of the Freundlich isotherm is written as:

$$
q_{e}=k_{F} C_{e}^{1 / n}
$$

Whereas the linear form of the Freundlich isotherm equation can be written as $[60,66]$ :

$$
\ln \left(q_{e}\right)=\ln \left(k_{F}\right)+\frac{1}{n} \ln \left(C_{e}\right)
$$

Where $\mathrm{K}_{\mathrm{F}}$ is the calculated Freundlich equilibrium constant $\left([\mathrm{mg} / \mathrm{g}][\mathrm{L} / \mathrm{mg}]^{1 / \mathrm{n}}\right)$ and is an indicator of adsorption capacity, and $\mathrm{n}$ is a measure of the deviation from linearity of adsorption $(\mathrm{g} / \mathrm{L})$.

\section{RESULTS AND DISCUSSION}

\subsection{Characterisation}

Figure 2 shows the $\mathrm{N}_{2}$ adsorption/desorption isotherms for $\mathrm{UiO}-66-\mathrm{Ca}$ samples and $\mathrm{UiO}-66$. Hysteresis in the desorption isotherm was distinguishably demonstrated by $\mathrm{UiO}-66-10 \% \mathrm{Ca}$ which had a sharp increase in adsorption at relative pressures close to 0.999 . This observation is strong evidence that the mesopore and macropore sizes were enhanced [67].

Table 1 Textural properties of the adsorbents based on $\mathrm{N}_{2}$ adsorption/isotherm.

\begin{tabular}{cccc}
\hline Adsorbents & $\begin{array}{c}\mathrm{S}_{\mathrm{BET}} \\
\left(\mathrm{m}^{2} \mathrm{~g}^{-1}\right)\end{array}$ & $\begin{array}{c}\text { Pore volume } \\
\left(\mathrm{cc} \mathrm{g}^{-1}\right)\end{array}$ & $\begin{array}{c}\text { Pore } \\
\text { diameter } \\
(\mathrm{nm})\end{array}$ \\
\hline UiO-66 & 1585.5 & 0.82 & 1.04 \\
$\mathrm{UiO}-66-10 \% \mathrm{Ca}$ & 918.115 & 1.10 & 2.39 \\
$\mathrm{UiO}-66-30 \% \mathrm{Ca}$ & 557.681 & 0.25 & 0.91 \\
\hline
\end{tabular}

In addition, Table 1 presents the textural properties of all adsorbents, according to the calculations of the $\mathrm{N}_{2}$ adsorption isotherm. The specific surface area $\left(\mathrm{S}_{\mathrm{BET}}\right)$ decreased with increasing content of a second metal. BET surface area in UiO-66 was $1585.50 \mathrm{~m}^{2} \cdot \mathrm{g}^{-1}$ and then decreased to 918.115 and $557.68 \mathrm{~m}^{2} \cdot \mathrm{g}^{-1}$ in UiO-66-10\%Ca and $\mathrm{UiO}-66(\mathrm{Zr})-30 \% \mathrm{Ca}$ respectively due to increasing the content of $\mathrm{Ca}$ in the synthesis process. The current BET values are acceptable when they compared with that in previous studies [68].

However, the pore volume and average pore size were enhanced in the MOFs with the lowest content of the second metal. The highest pore volume and pore size were seen in UiO-66-10\%Ca, which were $1.10 \mathrm{cc.g}{ }^{-1}$ and $2.39 \mathrm{~nm}$, respectively. The results indicate that the addition of low concentrations of the second metal in the single-pot synthesis, followed by the activation process using the solvent exchange method, enhanced the pore volume and pore size replacing the second metal by methanol molecules which were discarded by the heating in the second stage of the activation process [69].

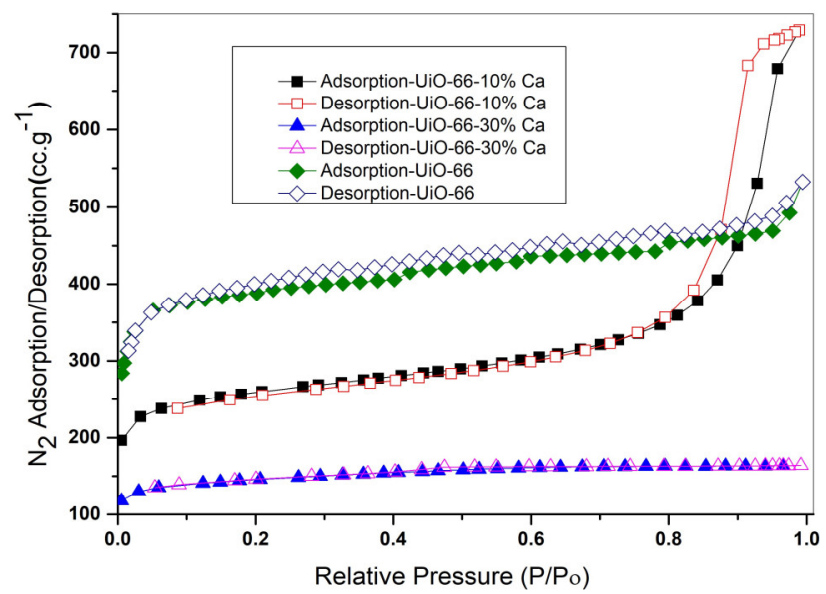

Fig. 2. $\mathrm{N}_{2}$ adsorption/Desorption Isotherm of UiO-66 and $\mathrm{UiO}-66(\mathrm{Zr})-\mathrm{Ca}$.

Figure 3(a) compares the XRD patterns of UiO-66-Ca with that of UiO-66. The results demonstrate that the integrity of the structure was maintained in activated samples, which indicates that the synthesis and activation procedures succeeded reliably without suspected impurities of a metal oxide inside the pores. The XRD patterns of activated samples are similar to the XRD pattern of UiO-66 in previous studies $[46,70,71]$. The patterns of the samples after using in the adsorption experiments in Figure 3a shows that $\mathrm{UiO}-66-30 \% \mathrm{Ca}$ demonstrated higher stability than other samples because the pattern of this sample displayed all peaks as same as those of activated samples. However, other samples were distinguished by the main characteristic peak in 2 theta of $7^{\circ}$ while other peaks were significantly reduced.

Figure 3(b) shows that the spectra of all samples, including that of $\mathrm{UiO}-66$, exhibit the same vibration bands with slight deviations in the position of some peaks with increases in the content of a second metal. In addition, the peaks in the mixed-metal samples were broader than the peaks in the single-metal $(\mathrm{Zr})$ sample, which indicates a difference in the dipole between ground state and excited state in the mixed-metal UiO-66 as a result of incorporating a second metal in the metal centre $[72,73]$. The vibration band of $1615-1580 \mathrm{~cm}^{-1}$ was attributed to $\mathrm{C}=\mathrm{C}-\mathrm{C}$ stretching in the aromatic ring of terephthalate salts; however, this band extended from 1590 to $1525 \mathrm{~cm}^{-1}$ in the mixed-metal UiO-66 [74]. Further, the bands at 1500 and $1390 \mathrm{~cm}^{-1}$ were attributed to the stretching vibrations of symmetric $\mathrm{COO}^{-}$and asymmetric $\mathrm{COO}^{-}$in coordinated organic linkers, as shown in the spectrum of $\mathrm{UiO}-66$.

Moreover, the weak bands at 881,812 and $785 \mathrm{~cm}^{-1}$ were assigned to $\mathrm{Zr}-\mathrm{O}$ whereas the peak at $730 \mathrm{~cm}^{-1}$ in the $\mathrm{UiO}-66$ spectrum was assigned to the stretching vibration of $\mathrm{C}-\mathrm{H}$ and out-of-plane bending of aromatic ring in the main skeleton of UiO-66; this peak was shifted to $744 \mathrm{~cm}^{-1}$ in the 
spectra of bimetal UiO-66 $[73,75]$. In addition, the band at $1017 \mathrm{~cm}^{-1}$ belonged to $\mathrm{C}-\mathrm{H}$ stretching in the MOF.

Figure 3(c) presents the results of thermogravimetric analysis for all adsorbents in this study. All samples appear to have the same thermal stability, with structural stability at increasing temperatures up to $725 \mathrm{~K}$.
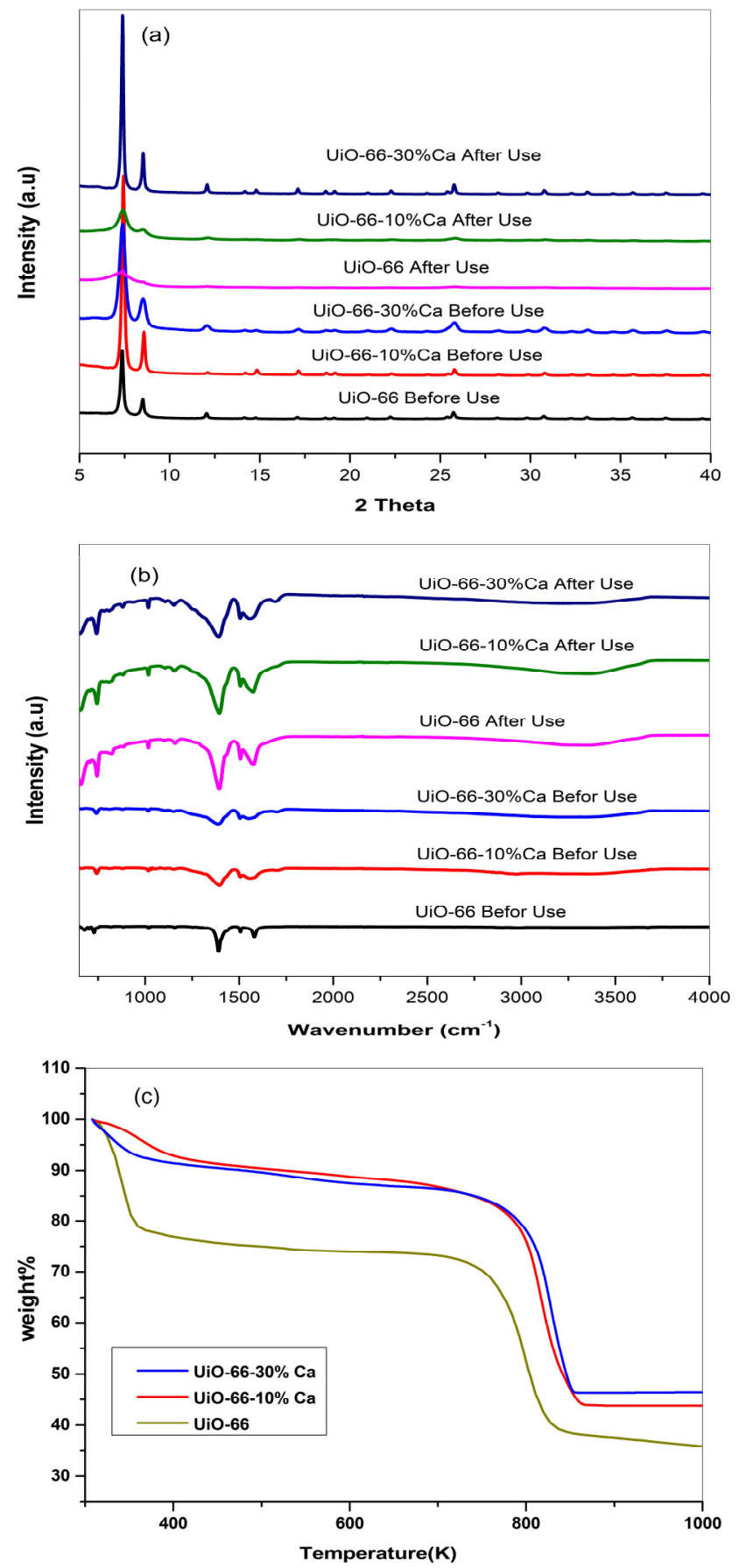

Fig. 3. Characterisation of UiO-66 samples. (a) PXRD patterns, (b) FTIR spectra and (c) TGA profiles of the UiO66 samples.

\subsection{Kinetic modelling study}

Figure $4 a-f$ describes the adsorption kinetics of $\mathrm{MB}$ by single-metal UiO-66 and bimetal UiO-66(Zr)-Ca. This Figure shows the amount of dye adsorbed $(\mathrm{mg} / \mathrm{g})$ on the adsorbents during different time periods $(\mathrm{min})$ for various initial concentrations of MB. For all MB concentrations, MB uptake at the commencement of the adsorption process is very rapid; after an initial period of time, it proceeds at a slower rate until the saturation is attained [76-78].

This phenomenon can be explained thus: the first available MB molecules are favourably adsorbed onto the most active sites of the single-metal and bimetal $\mathrm{Zr}-\mathrm{MOF}$, and the high initial MB uptake is possible because of the accessibility of many active sites. A longer contact time between the MOFs and MB results allows to increase the removal of $\mathrm{MB}$ until equilibrium adsorption capacity is reached [78]. Another explanation is that a higher initial concentration of $\mathrm{MB}$ provides more $\mathrm{MB}$ molecules and greater driving force of the aqueous phase $(\mathrm{MB})$ against the solid phase (MOFs) to overcome mass-transfer resistance. This fact gives rise to increase collisions between $\mathrm{MB}$ molecules and active sites on the adsorbent [79, 80]. For instance, the adsorption capacity for $\mathrm{MB}$ onto $\mathrm{UiO}-66$ at equilibrium increased from 2.151 to $14.837 \mathrm{mg}^{-1}$ with increase in $\mathrm{MB}$ concentration from 5 to $50 \mathrm{mg}$. $\mathrm{L}^{-1}$. Also, the adsorption capacity in $\mathrm{UiO}-66-\mathrm{Ca} 10 \%$ and $\mathrm{UiO}-66-30 \% \mathrm{Ca}$ was higher than that of UiO-66. It was reported that vacant metal sites in bimetallic MOFs are enhanced after removing the second metal by the solvent exchange activation[81]. Therefore, removing of $\mathrm{Ca}$ from UiO-66-Ca increased the active sites and consequently enhanced the adsorption capacity of MB [81].

The pseudo first-order and pseudo second-order model were employed for the adsorption of $\mathrm{MB}$ onto $\mathrm{UiO}-66, \mathrm{UiO}$ $66-10 \% \mathrm{Ca}$ and $\mathrm{UiO}-66-30 \% \mathrm{Ca}$. The linear regression correlation, $\mathrm{R}^{2}$, was calculated to identify the model of best fit; higher $\mathrm{R}^{2}$ values mean a better fit for the experimental data. The results of the correlational analysis of the amount of adsorbed dye $(\mathrm{mg} / \mathrm{g})$ against contact time, for the various initial concentrations of $\mathrm{MB}(5,15,30$ and $50 \mathrm{ppm})$ are shown in Figure 4. The results indicate that the amount of dye loading $\left(\mathrm{q}_{\mathrm{t}}[\mathrm{mg} / \mathrm{g}]\right)$ increases with contact time at each level of MB concentration. In addition, the amount of $M B$ adsorbed increased with increasing in the initial $\mathrm{MB}$ concentration [47].

The kinetics of the adsorption process in the laboratory -based on batch experiments enables the prediction of the rate at which a pollutant is removed from bulk solutions, which informs the design of adsorption treatment plant columns [82]. However, the physical and chemical properties of the adsorbent significantly affect its adsorption kinetics, which in turn, affects the sorption mechanism. Statistics from kinetics studies of pseudo first-order and pseudo second-order kinetics model equations have been investigated for fit with contact time data [76]. Tables 2 and 3 below present their main characteristics as calculated kinetic constants $\left(\mathrm{k}_{1}, \mathrm{k}_{2}\right)$ and correlation coefficients $\left(\mathrm{R}^{2}\right)$ for $\mathrm{C}_{\mathrm{i}}=5,15,30$ and $50 \mathrm{ppm}$.

According to the $\mathrm{R}^{2}$ values obtained, they have been consistent and closer to unity for the pseudo second-order kinetic equation than for the pseudo first-order kinetic equation. Therefore, based on $\mathrm{R}^{2}$ values, the sorption kinetics of $\mathrm{MB}$ removal using single-metal and bimetal $\mathrm{Zr}$ MOF were well described by the pseudo second-order kinetic equation. Further, the calculated equilibrium adsorption capacity agreed with the experimental 

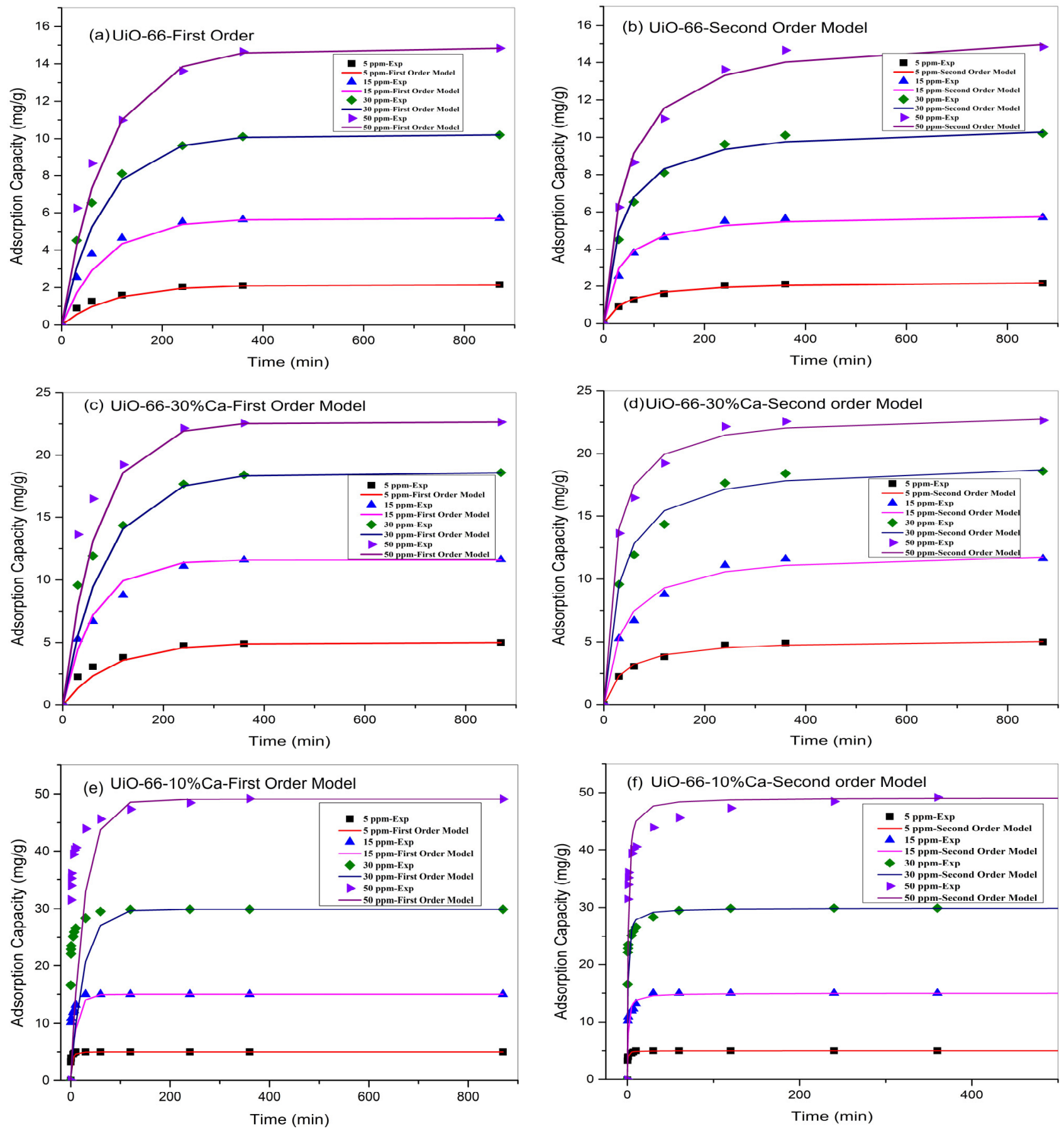

Fig. 4. Fitting of experimental data by first-order and second-order kinetic models of $\mathrm{MB}$ adsorption onto UiO-66 (a, b), UiO$66-30 \% \mathrm{Ca}(\mathrm{c}, \mathrm{d})$ and $\mathrm{UiO}-66-10 \% \mathrm{Ca}(\mathrm{e}, \mathrm{f})$.

equilibrium adsorption capacity, further indicating that the sorption of aqueous $\mathrm{MB}$ onto single-metal and bimetal Zr-MOF perfectly obeyed pseudo second-order kinetics that indicates strong interactions happened between $\mathrm{MB}$ and active sites in UiO-66 [83]. Specifically, the sorption of MB by single and bimetal Zr-MOFs occurred through chemisorption (the exchange or sharing of electrons between the sorbate and sorbent via covalent forces and ion exchange) $[56,83]$.

Based on the mechanism underlying pseudo second-order kinetics, the effects of the initial concentration on the adsorption kinetics of MB onto the three MOFs (i.e., all the sorbent systems) were similar over time. UiO-66-10\%
Ca was taken to be a representative adsorbent and was used to explain the effects of the initial concentration on the rate of adsorption. Precisely, Table 2 shows that the adsorption rate constants $\left(\mathrm{k}_{2}\right)$ of Pseudo second-order model on $\mathrm{UiO}$ 66-10\% Ca were higher than those on other adsorbents. Specifically, $\mathrm{k}_{2}$ on UiO-66-10\% Ca was $0.86348,0.07616$, 0.04628 and $0.02259 \mathrm{~g} \mathrm{mg}^{-1} \cdot \mathrm{min}^{-1}$ at initial $\mathrm{MB}$ concentrations of $5,15,30$ and $50 \mathrm{mg} . \mathrm{L}^{-1}$, respectively, signifying a decrease in adsorption rate at higher initial concentrations of MB. Reductions in the amount adsorbed at higher initial concentrations may be due to $\mathrm{MB}$ molecules having to enter the pores through a longer diffusion path. On the other hand, with less amounts of $\mathrm{MB}$ adsorbed, $\mathrm{MB}$ 
molecules tend to be rapidly adsorbed into the open pores of MOFs, which eventually increases the adsorption rate $\left(\mathrm{K}_{2}\right)$. Table 3 shows the kinetic constant of Pseudo first- order model $\left(\mathrm{K}_{2}\right)$ and $\mathrm{R}^{2}$. $\mathrm{K}_{1}$ of UiO-66-10\% Ca was also higher than that of UiO-66 and UiO-66-30\% Ca. For instance, it was $0.0101,0.2669$ and 0.0105 respectively at initial concentration of $5 \mathrm{ppm}$. The lower rate constant for MB adsorption onto the UiO-66-30\% was tentatively ascribed to $\mathrm{MB}$ diffusion into the micropores of the MOF [84].

Table 2 Calculated kinetics constant $\left(\mathrm{k}_{2}\right)$ and correlation coefficient $\left(\mathrm{R}^{2}\right)$ for $\mathrm{C}_{\mathrm{i}}=5,15,30$ and $50 \mathrm{ppm}$.

\begin{tabular}{|c|c|c|c|c|c|c|c|c|c|}
\hline \multirow{3}{*}{ Adsorbent } & \multirow{3}{*}{ Adsorbate } & \multicolumn{8}{|c|}{ Pseudo second-order kinetics constant $\mathrm{k}_{2}(\mathrm{~g} /(\mathrm{mg} \cdot \mathrm{min}))$} \\
\hline & & \multicolumn{2}{|c|}{$5 \mathrm{ppm}$} & \multicolumn{2}{|c|}{$15 \mathrm{ppm}$} & \multicolumn{2}{|c|}{$30 \mathrm{ppm}$} & \multicolumn{2}{|c|}{50 ppm } \\
\hline & & $\mathrm{k}_{2}$ & $\mathrm{R}^{2}$ & $\mathrm{k}_{2}$ & $\mathrm{R}^{2}$ & $\mathrm{k}_{2}$ & $\mathrm{R}^{2}$ & $\mathrm{k}_{2}$ & $\mathrm{R}^{2}$ \\
\hline $\mathrm{UiO}-66$ & $\mathrm{MB}$ & 0.01050 & 0.9989 & 0.00546 & 0.9992 & 0.00273 & 0.9992 & 0.00147 & 0.999 \\
\hline $\mathrm{UiO}-66-10 \% \mathrm{Ca}$ & MB & 0.86348 & 0.9999 & 0.07616 & 0.9963 & 0.04628 & 0.9999 & 0.02259 & 0.9998 \\
\hline $\mathrm{UiO}-66-30 \% \mathrm{Ca}$ & $\mathrm{MB}$ & 0.00498 & 0.9991 & 0.00212 & 0.9984 & 0.00167 & 0.9992 & 0.00217 & 0.9996 \\
\hline
\end{tabular}

Table 3 Calculated kinetics constant $\left(\mathrm{k}_{1}\right)$ and correlation coefficient $\left(\mathrm{R}^{2}\right)$ for $\mathrm{C}_{\mathrm{i}}=5,15,30$ and $50 \mathrm{ppm}$.

\begin{tabular}{|c|c|c|c|c|c|c|c|c|c|}
\hline \multirow{3}{*}{ Adsorbent } & \multirow{3}{*}{ Adsorbate } & \multicolumn{8}{|c|}{ Pseudo first-order kinetics constant $\mathrm{k}_{1}\left(\mathrm{~min}^{-1}\right)$} \\
\hline & & \multicolumn{2}{|c|}{$5 \mathrm{ppm}$} & \multicolumn{2}{|c|}{$15 \mathrm{ppm}$} & \multicolumn{2}{|c|}{$30 \mathrm{ppm}$} & \multicolumn{2}{|c|}{$50 \mathrm{ppm}$} \\
\hline & & $\mathrm{k}_{1}$ & $\mathrm{R}^{2}$ & $\mathrm{k}_{1}$ & $\mathrm{R}^{2}$ & $\mathrm{k}_{1}$ & $\mathrm{R}^{2}$ & $\mathrm{k}_{1}$ & $\mathrm{R}^{2}$ \\
\hline $\mathrm{UiO}-66$ & $\mathrm{MB}$ & 0.0101 & 0.9888 & 0.0119 & 0.9920 & 0.0120 & 0.9925 & 0.0113 & 0.9813 \\
\hline $\mathrm{UiO}-66-10 \% \mathrm{Ca}$ & $\mathrm{MB}$ & 0.2669 & 0.9716 & 0.0913 & 0.9731 & 0.0395 & 0.9886 & 0.0370 & 0.9920 \\
\hline $\mathrm{UiO}-66-30 \% \mathrm{Ca}$ & MB & 0.0105 & 0.9930 & 0.0161 & 0.9636 & 0.0118 & 0.9927 & 0.0144 & 0.9960 \\
\hline
\end{tabular}

\subsection{Intraparticle diffusion modelling study}

A multistep adsorption process consists of the mass transfer of $\mathrm{MB}$ from the solution to the surface of single-metal and bimetal UiO-66; this transfer determines the extent of reaction throughout the whole adsorption process [85]. Adsorption process mechanism of $\mathrm{MB}$ onto MOFs can be arranged into the following three stages:

1. Film diffusion: the initial stage of rapid adsorption

2. Successive intraparticle diffusion: the second stage of the process during which the adsorption rate slows

3. The final stage: the adsorption attains equilibrium and lasting constant.

Film diffusion is very fast because of the rapid sorption of MB to the surface of the MOF. This stage is featured by quick surface mass transfer caused by a large differential which acts as a driving force. This stage is when the most is adsorbed by adsorbents, according to Weng et al. [86]. Such a finding establishes MOF-MB systems as entailing a fast adsorption process. Consequently, these adsorbent systems are favourable alternatives for removing cationic dyes from wastewater effluent. The second stage, intraparticle diffusion, is slower because the occupation of $\mathrm{MB}$ molecules on many of the available external sites in the first step slows the diffusion of MB molecules into the pore spaces of the MOF [85].

The mechanism of MB sorption on the surface of MOF was investigated using contact time data. Specifically, experimental data were fitted to the intraparticle diffusion model (Equation 13) and the outcomes interpreted by plotting $\mathrm{q}_{\mathrm{t}}$ versus $\mathrm{t}^{1 / 2}$ in Figure 5. The most important aspects of the intraparticle diffusion plot are first, the linear portion and the intercept of the plot (c), which indicates the effects of the boundary layer on the adsorption process.

The second linear portion of the plot can be used to interpret intraparticle diffusion. The plot can be used to derive values for parameters, such as $\mathrm{k}_{\mathrm{p}}$ (the diffusion rate), $\mathrm{C}$ and $\mathrm{R}^{2}$, as presented in Table 4. The $\mathrm{k}_{\mathrm{p}}$ can be determined from the slope of the plot. The slope can be used to estimate the driving force of diffusion, which plays a critical role in the adsorption reaction. Experimental data analysis demonstrated that the $\mathrm{k}_{\mathrm{p}}$ values increased from 0.0991 to $0.638 \mathrm{mg}^{-1} \mathrm{~min}^{-(1 / 2)}$ with increases in the initial $\mathrm{MB}$ concentration from 5 to $50 \mathrm{mg} . \mathrm{L}^{-1}$. Therefore, higher initial concentrations of $\mathrm{MB}$ increase the driving force and subsequently increase the $\mathrm{MB}$ diffusion rate. Further, increasing initial $\mathrm{MB}$ concentrations over a similar range led to increases in the intercept value (C) from 0.5017 to $3.8144 \mathrm{mg}^{-1} \mathrm{~g}^{-1}$, suggesting that an initial high concentration of basic dye is associated with a stronger boundary layer effect in the sorption process. In addition, an increase in the intercept value $(\mathrm{C})$ can indicate the availability of $\mathrm{MB}$ on the boundary layer of UiO-66.

\subsection{Equilibrium modelling study}

Recent research has revealed that initial concentration of MB has a detrimental effect on adsorption process. Initial concentration of $\mathrm{MB}$ plays a role in determining removal efficiency of $\mathrm{MB}(\mathrm{R} \%)$ and equilibrium adsorption capacity $\left(\mathrm{q}_{\mathrm{e}}\right)$; indeed, the initial concentration of $\mathrm{MB}$ has profound consequences for $\mathrm{R} \%$ and $\mathrm{q}_{\mathrm{e}}$. The initial concentration of $\mathrm{MB}$ positively affected $\mathrm{q}_{e}$ and negatively affected $\mathrm{R} \%[60,78]$. The observed decrease in $\mathrm{MB}$ removal ( $\mathrm{R} \%$ values of $43.03 \%$ 
Table 4 Calculated kinetics constant $\left(\mathrm{k}_{\mathrm{p}}\right), \mathrm{C}$ and correlation coefficient $\left(\mathrm{R}^{2}\right)$ for $\mathrm{C}_{\mathrm{i}}=5,15,30$ and $50 \mathrm{ppm}$.

\begin{tabular}{|c|c|c|c|c|}
\hline \multirow[b]{3}{*}{ Adsorbent } & \multicolumn{4}{|c|}{ Adsorption mechanism } \\
\hline & \multicolumn{4}{|c|}{ Intraparticle diffusion model } \\
\hline & $\begin{array}{l}\text { Initial concentration of } \mathrm{MB} \\
\text { solution }\left(\mathrm{mg} \cdot \mathrm{L}^{-1}\right)\end{array}$ & $\frac{\mathrm{k}_{\mathrm{p}}}{\left(\mathrm{mg} \cdot \mathrm{g}^{-1} \min ^{-(1 / 2)}\right)}$ & $\mathrm{C}\left(\mathrm{mg} \cdot \mathrm{g}^{-1}\right)$ & $\mathrm{R}^{2}$ \\
\hline \multirow[t]{4}{*}{$\mathrm{UiO}-66$} & 5 & 0.0991 & 0.5017 & 0.9999 \\
\hline & 15 & 0.22 & 2.1455 & 0.9918 \\
\hline & 30 & 0.3955 & 3.5763 & 0.9884 \\
\hline & 50 & 0.638 & 3.8144 & 0.9959 \\
\hline \multirow[t]{4}{*}{$\mathrm{UiO}-66-10 \% \mathrm{Ca}$} & 5 & 0.4851 & 3.4862 & 0.9981 \\
\hline & 15 & 0.9352 & 9.927 & 0.9883 \\
\hline & 30 & 0.7581 & 23.867 & 0.9655 \\
\hline & 50 & 0.6585 & 39.364 & 0.9040 \\
\hline \multirow[t]{4}{*}{$\mathrm{UiO}-66-30 \% \mathrm{Ca}$} & 5 & 0.218 & 1.3901 & 0.9983 \\
\hline & 15 & 0.5641 & 2.4216 & 0.9951 \\
\hline & 30 & 0.7423 & 6.186 & 0.9999 \\
\hline & 50 & 0.727 & 11.013 & 0.9928 \\
\hline
\end{tabular}

to $29.67 \%$ ) by $\mathrm{UiO}-66$ samples was representative of the adsorption process in all systems and confirmed the occupation of all accessible active sites on the UiO-66 above a certain concentration of MB. However, the increase in equilibrium adsorption capacity $\left(\mathrm{q}_{\mathrm{e}}\right)$ from 2.15 to $14.83 \mathrm{mg} /$ $\mathrm{g}$ can be attributed to the higher adsorption rate and the use of all available active sites on UiO-66 samples for sorption at higher concentrations of MB.

Equilibrium isotherms were examined using the Langmuir and Freundlich isotherms. The assumption of the Langmuir isotherm is monolayer coverage of sorbate over a sorbent with homogenous surface $[5,63]$. It assumes that the adsorption process occurs at specific homogenous sites over the adsorbent; that is, when an MB molecule occupies a specific site, additional sorption cannot happen again at the same site. Successful implantation of the Langmuir adsorption isotherm has been undertaken to explain the adsorption of basic dyes such as MB from aqueous solutions [66].

According to Freundlich model, the favourability of adsorption can be estimated by the magnitude of the exponent $(1 / \mathrm{n})$, which predicts the feasibility of the adsorption process. The values of $\mathrm{n}$ must be greater than one for conditions to be favourable for an adsorption process [5, 87]. The constant $n$ values of $\mathrm{UiO}-66, \mathrm{UiO}-66-10 \% \mathrm{Ca}$ and UiO-66-30\%Ca have been calculated to be $1.29,5.01$ and 3.09 , respectively. These values confirm the favourability of adsorption of MB onto single-metal and bimetal Zr-MOF. The results of the correlational analysis for $\mathrm{K}_{\mathrm{F}}, \mathrm{n}$ and the linear regression coefficient $\left(\mathrm{R}^{2}\right)$ for the plot of the linear form of the Freundlich model are presented in Table 5.

Figure 6 illustrates the experimental equilibrium data and the predicted theoretical isotherms for the adsorption of $\mathrm{MB}$ onto single-metal and bimetal Zr-MOFs. It is apparent, from Figure 6 and the $\mathrm{R}^{2}$ values in Table 5, that there is closer fit between the experimental data and Freundlich isotherm compared to that with the Langmuir isotherm, at higher values of $\mathrm{R}^{2}$.

Analyses and calculations of the Langmuir and Freundlich plots revealed that the values of the linear regression correlation coefficient $\left(\mathrm{R}^{2}\right)$ for the Langmuir model are $0.9889,0.9951$ and 0.9821 , and for the Freundlich model $0.9979,0.9973$ and 0.9926 , for UiO-66, UiO-66-10\% $\mathrm{Ca}$ and $\mathrm{UiO}-66-30 \% \mathrm{Ca}$, respectively.

Further, Freundlich constants $\left(\mathrm{K}_{\mathrm{F}}\right)$ related to the bonding energy of $\mathrm{MB}$ molecules with single-metal and bimetal Zr-MOFs were greater than Langmuir constants which were related to the affinity of $\mathrm{MB}$ molecules to single-metal and bimetal $\mathrm{Zr}-\mathrm{MOF}$ in all cases. As a result, the adsorption of $\mathrm{MB}$ onto single-metal and bimetal $\mathrm{Zr}-\mathrm{MOF}$ occurred as multilayer adsorption on a heterogeneous surface. The calculated maximum monolayer adsorption capacity $\left(\mathrm{q}_{\mathrm{m}}\right)$ of $\mathrm{Zr}-\mathrm{MOF}$ for $\mathrm{MB}$ is $50.25 \mathrm{mg} / \mathrm{g}$ for UiO-66$10 \% \mathrm{Ca}$, a relatively satisfactory adsorption capacity (see Table 4). According to Langmuir isotherm, the calculated results for the separation factor $\left(\mathrm{R}_{\mathrm{L}}\right)$ are (0.89-0.44), (0.005 $-0.0005)$ and $(0.28-0.03)$ for $\mathrm{UiO}-66, \mathrm{UiO}-66-10 \% \mathrm{Ca}$ and $\mathrm{UiO}-66-30 \% \mathrm{Ca}$, respectively. $\mathrm{R}_{\mathrm{L}}$ values for the sorption of $\mathrm{MB}$ onto single-metal and bimetal UiO-66 are in the range of $0<\mathrm{R}_{\mathrm{L}}<1$, indicating that the adsorption was favourable. Further, higher initial $\mathrm{MB}$ concentrations in the adsorption process can make it irreversible [88].

Table 6 lists the maximum adsorption capacity $\left(\mathrm{q}_{\mathrm{m}}\right)$ of the UiO-66 adsorbents in this study for $\mathrm{MB}$, relative to those reported in the literature for different adsorbents of $M B$. The performance of $\mathrm{UiO}-66$ in $\mathrm{MB}$ removal is relatively effective by comparison. 

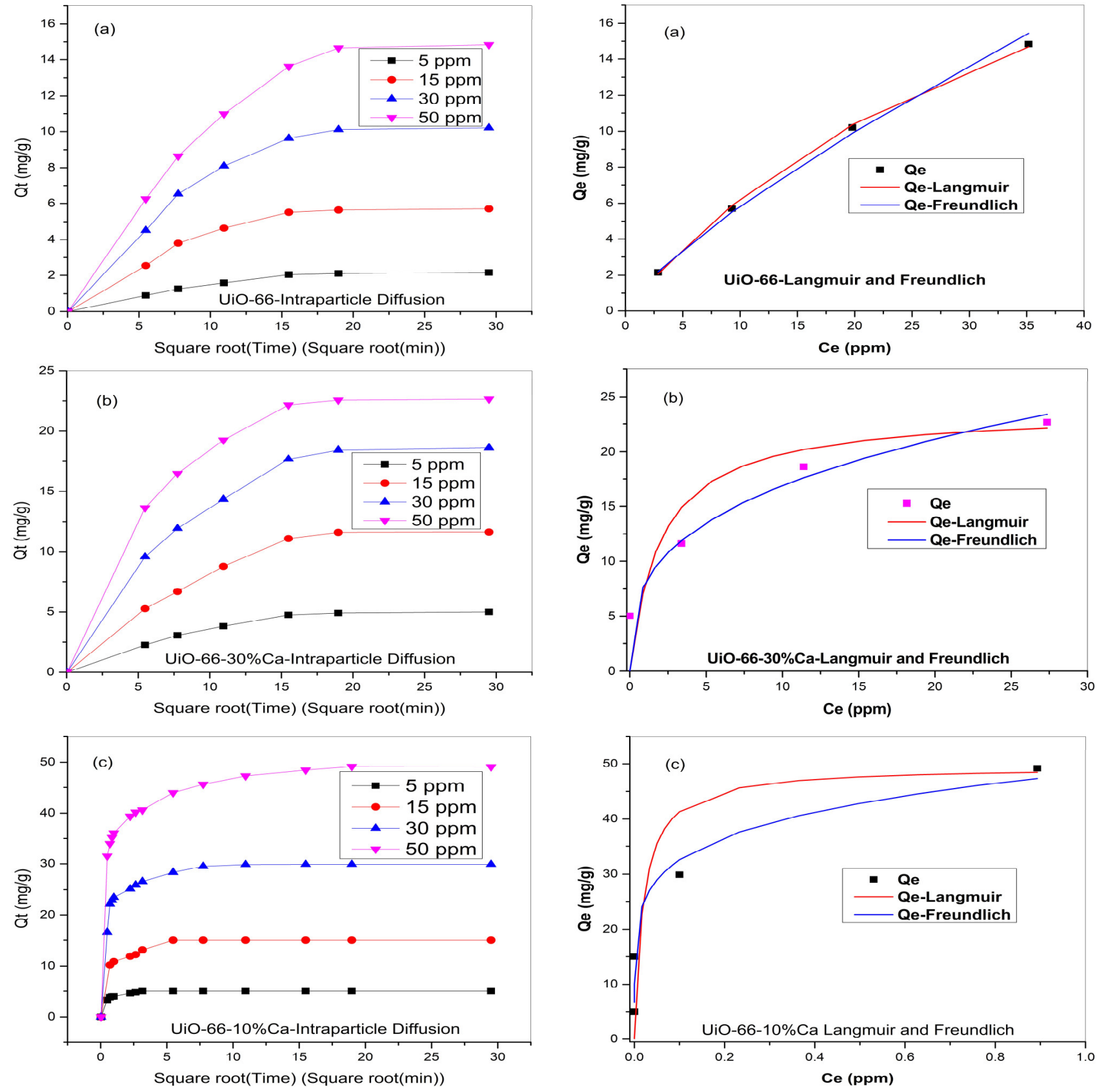

Fig. 5. Fitting of experimental data using intraparticle diffusion models of $\mathrm{MB}$ adsorption onto UiO-66 (a), UiO-66 $-30 \% \mathrm{Ca}(\mathrm{b})$ and $\mathrm{UiO}-66-10 \% \mathrm{Ca}(\mathrm{c})$.

Fig. 6. Fitting of experimental data using Langmuir and Freundlich models of MB adsorption onto UiO-66 (a), UiO66-30\% Ca (b) and UiO-66-10\%Ca (c).

Table 5 Calculated equilibrium constants $\left(\mathrm{k}_{\mathrm{L}}, \mathrm{k}_{\mathrm{F}}, \mathrm{q}_{\mathrm{m}}, \mathrm{n}\right.$ and correlation coefficient $\left.\left(\mathrm{R}^{2}\right)\right)$ of MB adsorption onto UiO-66, UiO66-30\% Ca and $\mathrm{UiO}-66-10 \% \mathrm{Ca}$ for $\mathrm{C}_{\mathrm{i}}=5,15,30$ and $50 \mathrm{ppm}$.

\begin{tabular}{|c|c|c|c|c|}
\hline Adsorbent & Adsorption isotherm model & Parameter & Value & $\mathrm{R}^{2}$ \\
\hline \multirow{4}{*}{$\mathrm{UiO}-66$} & \multirow{2}{*}{ Langmuir } & $\mathrm{q}_{\mathrm{m}}(\mathrm{mg} / \mathrm{g})$ & 31.74 & \multirow{2}{*}{0.9889} \\
\hline & & $\mathrm{K}_{\mathrm{L}}(\mathrm{L} / \mathrm{mg})$ & 0.02447 & \\
\hline & \multirow{2}{*}{ Freundlich } & $\mathrm{K}_{\mathrm{F}}\left([\mathrm{mg} / \mathrm{g}][\mathrm{L} / \mathrm{mg}]^{1 / \mathrm{n}}\right)$ & 0.98157 & \multirow{2}{*}{0.9979} \\
\hline & & $\mathrm{n}(\mathrm{g} / \mathrm{L})$ & 1.2918 & \\
\hline \multirow{4}{*}{$\mathrm{UiO}-66-10 \% \mathrm{Ca}$} & \multirow{2}{*}{ Langmuir } & $\mathrm{q}_{\mathrm{m}}(\mathrm{mg} / \mathrm{g})$ & 50.2512 & \multirow{2}{*}{0.9951} \\
\hline & & $\mathrm{K}_{\mathrm{L}}(\mathrm{L} / \mathrm{mg})$ & 39.8 & \\
\hline & \multirow{2}{*}{ Freundlich } & $\mathrm{K}_{\mathrm{F}}\left([\mathrm{mg} / \mathrm{g}][\mathrm{L} / \mathrm{mg}]^{1 / \mathrm{n}}\right)$ & 47.9855 & \multirow{2}{*}{0.9973} \\
\hline & & $\mathrm{n}(\mathrm{g} / \mathrm{L})$ & 5.0150 & \\
\hline \multirow{4}{*}{$\mathrm{UiO}-66-30 \% \mathrm{Ca}$} & \multirow{2}{*}{ Langmuir } & $\mathrm{q}_{\mathrm{m}}(\mathrm{mg} / \mathrm{g})$ & 23.7529 & \multirow{2}{*}{0.9821} \\
\hline & & $\mathrm{K}_{\mathrm{L}}(\mathrm{L} / \mathrm{mg})$ & 0.4982 & \\
\hline & \multirow{2}{*}{ Freundlich } & $\mathrm{K}_{\mathrm{F}}\left([\mathrm{mg} / \mathrm{g}][\mathrm{L} / \mathrm{mg}]^{1 / \mathrm{n}}\right)$ & 8.0164 & \multirow{2}{*}{0.9926} \\
\hline & & $\mathrm{n}(\mathrm{g} / \mathrm{L})$ & 3.0911 & \\
\hline
\end{tabular}


Table 6 Comparison of monolayer equilibrium capacity for methylene blue onto different adsorbents.

\begin{tabular}{lcc}
\hline \multicolumn{1}{c}{ Adsorbent } & $\mathrm{q}_{\mathrm{m}}(\mathrm{mg} / \mathrm{g})$ & Reference \\
\hline Untreated coffee husks & 90.1 & {$[89]$} \\
Sewage sludge from agrifood industry wastewater treatment plant & 86.957 & {$[90]$} \\
Raw date pits & 80.29 & {$[91]$} \\
Calcined pure clay & 56.31 & {$[92]$} \\
UiO-66-10\%Ca & 50.25 & This study \\
UiO-66-30\%Ca & 23.75 & This study \\
UiO-66 & 14.52 & This study \\
Luffa cylindrica fibres & 47 & {$[57]$} \\
Carbon nanotubes & 46.2 & {$[93]$} \\
Rice husk & 40.59 & {$[95]$} \\
Garden grass & 31.4 & {$[92]$} \\
Raw clay & 27.49 & {$[96]$} \\
Jute processing waste & 22.47 & {$[60]$} \\
Fe (III)/Cr $(\mathrm{III})$ hydroxide & 22.8 & {$[97]$} \\
Banana peel & 20.8 & {$[97]$} \\
Orange peel & 18.6 & {$[91]$} \\
Activated date pits $\left(\mathrm{T}=900^{\circ} \mathrm{C}\right)$ & 17.27 & {$[98]$} \\
Fly-ash & 13.42 & {$[92]$} \\
Calcined raw clay & 13.44 & {$[91]$} \\
Activated date pits $\left(\mathrm{T}=500^{\circ} \mathrm{C}\right)$ & 12.94 & {$[99]$} \\
Zeolite & 12.7 & {$[100]$} \\
Flay & 6.3 & {$[.3$} \\
\hline
\end{tabular}

\section{CONCLUSION}

The main goal of the current study was to assess the adsorption capacity of $\mathrm{MB}$ in $\mathrm{UiO}-66, \mathrm{UiO}-66-10 \% \mathrm{Ca}$ and $\mathrm{UiO}-66-30 \% \mathrm{Ca}$. The $\mathrm{Zr}$-MOFs were prepared according to a single pot solvothermal methods with a modification using trace additives of $\mathrm{Ca}$. Compared with the UiO-66 without the modification; the textural properties of the modified UiO-66 were enriched while their performances were enhanced to remove MB from wastewater. The kinetics of MB sorption onto UiO-66, UiO-66-10\% $\mathrm{Ca}$ and UiO-66$30 \% \mathrm{Ca}$ were fitted by the pseudo first and second-order models. The second model offered the best fit for the experimental data for all systems studied. The mechanism of MB sorption onto the surface of MOFs was investigated using contact time data. Specifically, the fitting of experimental data to the intraparticle diffusion model identified three stages in the sorption process.

Langmuir and Freundlich plot analyses and calculations revealed that the values of the linear regression correlation coefficient $\left(\mathrm{R}^{2}\right)$ for the Freundlich model were greater than those for the Langmuir model, for UiO-66, $\mathrm{UiO}$ $-66-10 \% \mathrm{Ca}$ and $\mathrm{UiO}-66-30 \% \mathrm{Ca}$. As a result, the adsorption of $\mathrm{MB}$ onto single-metal and bimetal Zr-MOFs was considered to occur as multilayer adsorption on a heterogeneous surface.

Langmuir maximum loading capacity $\left(\mathrm{q}_{\mathrm{m}}\right)$ was compared with other reported adsorbents in previous studies. The values of the separation factor $\left(R_{L}\right)$ indicated that the adsorption was a favourable process. Using the
Freundlich linear model, constant $\mathrm{n}$ values for $\mathrm{UiO}-66, \mathrm{UiO}-$ $66-10 \% \mathrm{Ca}$, and UiO-66-30\%Ca were found to be more than one (i.e., $n>1$ ). These values confirm the favourability of $\mathrm{MB}$ adsorption onto single-metal and bimetal Zr-MOF. This study can suggest the bimetallic UiO-66 as an attractive adsorbent to remove dyes from wastewater.

\section{AUTHOR INFORMATION}

Corresponding Author

*Email : naser.alamery@postgrad.curtin.edu.au

ORCID (1)

Shaobin Wang : :0000-0002-1751-9162

Shaomin Liu : :0000-0001-5019-5182

\section{REFERENCES}

[1] Almeida CAP, Debacher NA, Downs AJ, Cottet L, Mello CAD. Removal of methylene blue from colored effluents by adsorption on montmorillonite clay. Journal of Colloid and Interface Science 2009;332 (1):46-53

[2] Bhattacharyya KG, Sharma A. Kinetics and thermo dynamics of methylene blue adsorption on neem (Azadirachta indica) leaf powder. Dyes and pigments 2005;65(1):51-9.

[3] Tunç Ö, Tanacı H, Aksu Z. Potential use of cotton plant wastes for the removal of Remazol Black B reactive dye. Journal of Hazardous Materials 2009; 163 (1):187-98. 
[4] Albert M, Lessin MS, Gilchrist BF. Methylene blue: dangerous dye for neonates. Journal of Pediatric Surgery 2003;38(8):1244-5.

[5] Hameed BH. Spent tea leaves: A new nonconventional and low-cost adsorbent for removal of basic dye from aqueous solutions. Journal of Hazardous Materials 2009;161(2):753-9.

[6] Abdelrahman EA, Hegazey R, El-Azabawy RE. Efficient removal of methylene blue dye from aqueous media using $\mathrm{Fe} / \mathrm{Si}, \mathrm{Cr} / \mathrm{Si}, \mathrm{Ni} / \mathrm{Si}$, and $\mathrm{Zn} / \mathrm{Si}$ amorphous novel adsorbents. Journal of Materials Research and Technology 2019;8(6):5301-13.

[7] Rafatullah M, Sulaiman O, Hashim R, Ahmad A. Adsorption of methylene blue on low-cost adsorbents: A review. Journal of Hazardous Materials 2010;177 (1):70-80.

[8] Gupta VK, Suhas, Ali I, Saini VK. Removal of Rhodamine B, Fast Green, and Methylene Blue from Wastewater Using Red Mud, an Aluminum Industry Waste. Industrial \& Engineering Chemistry Research 2004;43(7):1740-7.

[9] Robinson T, McMullan G, Marchant R, Nigam P. Remediation of dyes in textile effluent: a critical review on current treatment technologies with a proposed alternative. Bioresource Technology 2001;77(3): 247-55.

[10] Wang S, Zhu Z. Characterisation and environmental application of an Australian natural zeolite for basic dye removal from aqueous solution. Journal of hazardous materials 2006;136(3):946-52.

[11] Bulut Y, Aydin H. A kinetics and thermodynamics study of methylene blue adsorption on wheat shells. Desalination 2006;194(1):259-67.

[12] Meshko V, Markovska L, Mincheva M, Rodrigues AE. Adsorption of basic dyes on granular acivated carbon and natural zeolite. Water Research 2001;35(14):3357 $-66$.

[13] Wang S, Zhu ZH. Characterisation and environmental application of an Australian natural zeolite for basic dye removal from aqueous solution. Journal of Hazardous Materials 2006;136(3):946-52.

[14] Wang S, Boyjoo Y, Choueib A, Zhu ZH. Removal of dyes from aqueous solution using fly ash and red mud. Water Research 2005;39(1):129-38.

[15] Akbal F. Adsorption of basic dyes from aqueous solution onto pumice powder. Journal of colloid and interface science 2005;286(2):455-8.

[16] Yaghi OM, O'keeffe M, Ockwig NW, Chae HK, Eddaoudi M, Kim J. Reticular synthesis and the design of new materials. Nature 2003;423(6941):705.

[17] Yaghi OM, Li H, Davis C, Richardson D, Groy TL. Synthetic Strategies, Structure Patterns, and Emerging Properties in the Chemistry of Modular Porous Solids. Accounts of Chemical Research 1998;31(8):474-84.

[18] Batten SR, Robson R. Interpenetrating nets: ordered, periodic entanglement. Angewandte Chemie International Edition 1998;37(11):1460-94.

[19] Férey G. Building units design and scale chemistry. Journal of Solid State Chemistry 2000;152(1):37-48.
[20] Kitagawa S, Kondo M. Functional micropore chemistry of crystalline metal complex-assembled compounds. Bulletin of the Chemical Society of Japan 1998;71 (8):1739-53.

[21] Yaghi O, O'Keeffe M, Kanatzidis M. Design of solids from molecular building blocks: golden opportunities for solid state chemistry. Journal of Solid State Chemistry 2000;152(1):1-2.

[22] Furukawa H, Cordova KE, O'Keeffe M, Yaghi OM. The chemistry and applications of metal-organic frameworks. Science 2013;341(6149): 1230444.

[23] Zhou H-C, Long JR, Yaghi OM. Introduction to metal -organic frameworks. ACS Publications; 2012.

[24] Mueller U, Schubert M, Teich F, Puetter H, Schierle-Arndt K, Pastre J. Metal-organic frameworksprospective industrial applications. Journal of Materials Chemistry 2006;16(7):626-36.

[25] Jacoby M. Heading to market with MOFs. Chem Eng News 2008;86(34):13-6.

[26] Furukawa H, Ko N, Go YB, Aratani N, Choi SB, Choi $\mathrm{E}$, et al. Ultrahigh porosity in metal-organic frameworks. Science 2010;329(5990):424-8.

[27] Millward AR, Yaghi OM. Metal- organic frameworks with exceptionally high capacity for storage of carbon dioxide at room temperature. Journal of the American Chemical Society 2005;127(51):17998-9.

[28] Caskey SR, Wong-Foy AG, Matzger AJ. Dramatic tuning of carbon dioxide uptake via metal substitution in a coordination polymer with cylindrical pores. Journal of the American Chemical Society 2008;130 (33):10870-1.

[29] Hamon L, Serre C, Devic T, Loiseau T, Millange F, Férey $\mathrm{G}$, et al. Comparative study of hydrogen sulfide adsorption in the MIL-53 (Al, Cr, Fe), MIL-47 (V), MIL-100 (Cr), and MIL-101 (Cr) metal- organic frameworks at room temperature. Journal of the American Chemical Society 2009;131(25):8775-7.

[30] Karra JR, Walton KS. Effect of open metal sites on adsorption of polar and nonpolar molecules in metal- organic framework Cu-BTC. Langmuir 2008;24(16):8620-6.

[31] Blanco-Brieva G, Campos-Martin JM, Al-Zahrani S, Fierro JL. Effectiveness of metal-organic frameworks for removal of refractory organo-sulfur compound present in liquid fuels. Fuel 2011;90(1):190-7.

[32] Arstad B, Fjellvåg H, Kongshaug KO, Swang O, Blom R. Amine functionalised metal organic frameworks (MOFs) as adsorbents for carbon dioxide. Adsorption 2008;14(6):755-62.

[33] Haque E, Lee JE, Jang IT, Hwang YK, Chang J-S, Jegal $\mathrm{J}$, et al. Adsorptive removal of methyl orange from aqueous solution with metal-organic frameworks, porous chromium-benzenedicarboxylates. Journal of Hazardous Materials 2010;181(1):535-42.

[34] Peterson GW, Wagner GW, Balboa A, Mahle J, Sewell T, Karwacki CJ. Ammonia vapor removal by $\mathrm{Cu} 3$ (BTC) 2 and its characterization by MAS NMR. The Journal of Physical Chemistry C 2009;113(31): 13906-17. 
[35] Khan NA, Jhung SH. Adsorptive removal of benzothiophene using porous copper-benzenetricarboxylate loaded with phosphotungstic acid. Fuel Processing Technology 2012;100:49-54.

[36] Khan NA, Hasan Z, Jhung SH. Adsorptive removal of hazardous materials using metal-organic frameworks (MOFs): A review. Journal of Hazardous Materials 2013;244-245:444-56.

[37] Khan NA, Jun JW, Jeong JH, Jhung SH. Remarkable adsorptive performance of a metal-organic framework, vanadium-benzenedicarboxylate (MIL-47), for benzothiophene. Chemical Communications 2011;47 (4):1306-8.

[38] Ahmed I, Hasan Z, Khan NA, Jhung SH. Adsorptive denitrogenation of model fuels with porous metal-organic frameworks (MOFs): Effect of acidity and basicity of MOFs. Applied Catalysis B: Environmental 2013;129:123-9.

[39] Khan NA, Jhung SH. Low-temperature loading of $\mathrm{Cu}+$ species over porous metal-organic frameworks (MOFs) and adsorptive desulfurization with $\mathrm{Cu}+-$ loaded MOFs. Journal of Hazardous Materials 2012;237-238:180-5.

[40] Britt D, Tranchemontagne D, Yaghi OM. Metal-organic frameworks with high capacity and selectivity for harmful gases. Proceedings of the National Academy of Sciences 2008;105(33):11623-7.

[41] Hamon L, Leclerc H, Ghoufi A, Oliviero L, Travert A, Lavalley $\mathrm{J}-\mathrm{C}$, et al. Molecular insight into the adsorption of $\mathrm{H} 2 \mathrm{~S}$ in the flexible MIL-53 (Cr) and rigid MIL-47 (V) MOFs: infrared spectroscopy combined to molecular simulations. The Journal of Physical Chemistry C 2011;115(5):2047-56.

[42] Mo Z-W, Zhou H-L, Zhou D-D, Lin R-B, Liao P-Q, He $\mathrm{C}-\mathrm{T}$, et al. Mesoporous Metal-Organic Frameworks with Exceptionally High Working Capacities for Adsorption Heat Transformation. Advanced Materials 2018;30(4):1704350.

[43] Xue H, Huang X-S, Yin Q, Hu X-J, Zheng H-Q, Huang $\mathrm{G}$, et al. Bimetallic Cationic Metal-Organic Frameworks for Selective Dye Adsorption and Effective Cr2O72- Removal. Crystal Growth \& Design 2020;20 (8):4861-6.

[44] Azhar MR, Abid HR, Periasamy V, Sun H, Tade MO, Wang S. Adsorptive removal of antibiotic sulfonamide by UiO-66 and ZIF-67 for wastewater treatment. Journal of Colloid and Interface Science 2017;500: 88-95.

[45] Al Amery N, Abid HR, Wang S, Liu S. Enhancing Acidic Dye Adsorption by Updated Version of UiO-66. Journal of Applied Materials and Technology 2020;1 (2):54-62.

[46] Abid HR, Pham GH, Ang H-M, Tade MO, Wang S. Adsorption of $\mathrm{CH} 4$ and $\mathrm{CO} 2$ on $\mathrm{Zr}$-metal organic frameworks. Journal of Colloid and Interface Science 2012;366(1):120-4.

[47] Hameed BH, Ahmad AA. Batch adsorption of methylene blue from aqueous solution by garlic peel, an agricultural waste biomass. Journal of Hazardous Materials 2009;164(2):870-5.
[48] Hameed B, Rahman A. Removal of phenol from aqueous solutions by adsorption onto activated carbon prepared from biomass material. Journal of Hazardous Materials 2008;160(2):576-81.

[49] Ho Y-S, McKay G. Pseudo-second order model for sorption processes. Process biochemistry 1999;34 (5):451-65.

[50] Wang S, Li H, Xu L. Application of zeolite MCM-22 for basic dye removal from wastewater. Journal of colloid and interface science 2006;295(1):71-8.

[51] Weber WJ, Morris JC. Kinetics of adsorption on carbon from solution. Journal of the Sanitary Engineering Division 1963;89(2):31-60.

[52] Gupta N, Kushwaha AK, Chattopadhyaya MC. Application of potato (Solanum tuberosum) plant wastes for the removal of methylene blue and malachite green dye from aqueous solution. Arabian Journal of Chemistry 2016;9:S707-S16.

[53] Lin S-H, Juang R-S. Adsorption of phenol and its derivatives from water using synthetic resins and low-cost natural adsorbents: a review. Journal of environmental management 2009;90(3):1336-49.

[54] Uddin MT, Islam MA, Mahmud S, Rukanuzzaman M. Adsorptive removal of methylene blue by tea waste. Journal of Hazardous Materials 2009;164(1):53-60.

[55] Lagergren S. Zur theorie der sogenannten adsorption gel`ster stoffe, Kungliga Svenska Vetenskapsakademiens. Handlingar. 24 (4), 1-39. Microchemical Journal Environ Sci Technol J Colloid Interface Sci J Colloid Interface Sci Environ Sci Technol Rev Soc Quím Perú, American Water Works Association Chem Eng 1898.

[56] Ho YS, McKay G. Pseudo-second order model for sorption processes. Process Biochemistry 1999;34 (5):451-65.

[57] Demir H, Top A, Balköse D, Ülkü S. Dye adsorption behavior of Luffa cylindrica fibers. Journal of Hazardous Materials 2008;153(1-2):389-94.

[58] Rattanaphani S, Chairat M, Bremner JB, Rattanaphani V. An adsorption and thermodynamic study of lac dyeing on cotton pretreated with chitosan. Dyes and pigments 2007;72(1):88-96.

[59] Moussavi G, Khosravi R. The removal of cationic dyes from aqueous solutions by adsorption onto pistachio hull waste. Chemical Engineering Research and Design 2011;89(10):2182-9.

[60] Namasivayam C, Sumithra S. Removal of direct red $12 \mathrm{~B}$ and methylene blue from water by adsorption onto $\mathrm{Fe}$ (III)/Cr (III) hydroxide, an industrial solid waste. Journal of Environmental Management 2005;74 (3):207-15.

[61] Gupta G, Prasad G, Panday K, Singh V. Removal of chrome dye from aqueous solutions by fly ash. Water, Air, and Soil Pollution 1988;37(1-2):13-24.

[62] Hameed BH, Ahmad AL, Latiff KNA. Adsorption of basic dye (methylene blue) onto activated carbon prepared from rattan sawdust. Dyes and Pigments 2007;75(1):143-9.

[63] Hameed BH, Din ATM, Ahmad AL. Adsorption of methylene blue onto bamboo-based activated carbon: 
Kinetics and equilibrium studies. Journal of Hazardous Materials 2007;141(3):819-25.

[64] Hall KR, Eagleton LC, Acrivos A, Vermeulen T. Pore-and solid-diffusion kinetics in fixed-bed adsorption under constant-pattern conditions. Industrial \& Engineering Chemistry Fundamentals 1966;5(2):212-23.

[65] Gupta GS, Prasad G, Panday KK, Singh VN. Removal of chrome dye from aqueous solutions by fly ash. Water, Air, and Soil Pollution 1988;37(1):13-24.

[66] Kumar KV, Ramamurthi V, Sivanesan S. Modeling the mechanism involved during the sorption of methylene blue onto fly ash. Journal of colloid and interface science 2005;284(1):14-21.

[67] Abid HR, Ang HM, Wang S. Effects of ammonium hydroxide on the structure and gas adsorption of nanosized Zr-MOFs (UiO-66). Nanoscale 2012;4 (10):3089-94.

[68] Rada ZH, Abid HR, Sun H, Wang S. Bifunctionalized Metal Organic Frameworks, UiO-66-NO2-N ( $\mathrm{N}=$ $-\mathrm{NH} 2, \quad-(\mathrm{OH}) 2, \quad-(\mathrm{COOH}) 2), \quad$ for Enhanced Adsorption and Selectivity of CO2 and N2. Journal of Chemical \& Engineering Data 2015;60(7):2152-61.

[69] Al Haydar M, Abid HR, Sunderland B, Wang S. Multimetal organic frameworks as drug carriers: aceclofenac as a drug candidate. Drug Des Devel Ther 2018;13:23-35.

[70] Abid HR, Tian H, Ang H-M, Tade MO, Buckley CE, Wang S. Nanosize Zr-metal organic framework (UiO66) for hydrogen and carbon dioxide storage. Chemical Engineering Journal 2012;187:415-20.

[71] Abid HR, Shang J, Ang H-M, Wang S. Amino-functionalized $\mathrm{Zr}-\mathrm{MOF}$ nanoparticles for adsorption of $\mathrm{CO} 2$ and $\mathrm{CH} 4$. International Journal of Smart and Nano Materials 2013;4(1):72-82.

[72] Di Marino A, Mendicuti F. Thermodynamics of complexation of dimethyl esters of tere-, iso-, and phthalic acids with $\alpha$-and $\beta$-cyclodextrins. Applied spectroscopy 2004;58(7):823-30.

[73] Dhumal NR, Singh MP, Anderson JA, Kiefer J, Kim HJ. Molecular Interactions of a Cu-Based Metal-Organic Framework with a Confined Imidazolium-Based Ionic Liquid: A Combined Density Functional Theory and Experimental Vibrational Spectroscopy Study. The Journal of Physical Chemistry C 2016;120(6):3295304.

[74] Coates J. Interpretation of infrared spectra, a practical approach. Encyclopedia of analytical chemistry 2000;12:10815-37.

[75] Aroke U, Abdulkarim A, Ogubunka R. Fouriertransform infrared characterization of kaolin, granite, bentonite and barite. ATBU Journal of Environmental Technology 2013;6(1):42-53.

[76] Ho Y, McKay G. The kinetics of sorption of basic dyes from aqueous solution by sphagnum moss peat. The Canadian Journal of Chemical Engineering 1998;76 (4):822-7.

[77] Bulut Y, Aydın H. A kinetics and thermodynamics study of methylene blue adsorption on wheat shells. Desalination 2006;194(1-3):259-67.
[78] Senthil Kumar P, Senthamarai C, Durgadevi A. Adsorption kinetics, mechanism, isotherm, and thermodynamic analysis of copper ions onto the surface modified agricultural waste. Environmental Progress \& Sustainable Energy 2014;33(1):28-37.

[79] Ai L, Jiang J. Fast removal of organic dyes from aqueous solutions by $\mathrm{AC} /$ ferrospinel composite. Desalination 2010;262(1):134-40.

[80] Ai L, Zhang C, Chen Z. Removal of methylene blue from aqueous solution by a solvothermal-synthesized graphene/magnetite composite. Journal of Hazardous Materials 2011;192(3):1515-24.

[81] Abid HR, Rada ZH, Li Y, Mohammed HA, Wang Y, Wang $\mathrm{S}$, et al. Boosting $\mathrm{CO} 2$ adsorption and selectivity in metal-organic frameworks of MIL-96(Al) via second metal Ca coordination. RSC Advances 2020;10 (14):8130-9.

[82] Doğan M, Özdemir Y, Alkan M. Adsorption kinetics and mechanism of cationic methyl violet and methylene blue dyes onto sepiolite. Dyes and Pigments 2007;75(3):701-13.

[83] Zaboon S, Abid HR, Yao Z, Gubner R, Wang S, Barifcani A. Removal of monoethylene glycol from wastewater by using Zr-metal organic frameworks. Journal of Colloid and Interface Science 2018;523: 75-85.

[84] Ji B, Shao F, Hu G, Zheng S, Zhang Q Xu Z. Adsorption of methyl tert-butyl ether (MTBE) from aqueous solution by porous polymeric adsorbents. Journal of Hazardous Materials 2009;161(1):81-7.

[85] Gupta N, Kushwaha AK, Chattopadhyaya M. Adsorption studies of cationic dyes onto Ashoka (Saraca asoca) leaf powder. Journal of the Taiwan Institute of Chemical Engineers 2012;43(4):604-13.

[86] Weng C-H, Lin Y-T, Tzeng T-W. Removal of methylene blue from aqueous solution by adsorption onto pineapple leaf powder. Journal of Hazardous Materials 2009;170(1):417-24.

[87] Ho Y-S, McKay G. Sorption of dye from aqueous solution by peat. Chemical engineering journal 1998;70(2):115-24.

[88] Ponnusami V, Vikram S, Srivastava SN. Guava (Psidium guajava) leaf powder: Novel adsorbent for removal of methylene blue from aqueous solutions. Journal of Hazardous Materials 2008;152(1):276-86.

[89] Oliveira LS, Franca AS, Alves TM, Rocha SD. Evaluation of untreated coffee husks as potential biosorbents for treatment of dye contaminated waters. Journal of Hazardous Materials 2008;155(3):507-12.

[90] Otero M, Rozada F, Calvo LF, Garcı®a AI, Morán A. Kinetic and equilibrium modelling of the methylene blue removal from solution by adsorbent materials produced from sewage sludges. Biochemical Engineering Journal 2003;15(1):59-68.

[91] Banat F, Al-Asheh S, Al-Makhadmeh L. Evaluation of the use of raw and activated date pits as potential adsorbents for dye containing waters. Process Biochemistry 2003;39(2):193-202.

[92] Ghosh D, Bhattacharyya K. Removing colour from aqueous medium by sorption on natural clay: a study 
with methylene blue. INDIAN JOURNAL OF ENVIRONMENTAL PROTECTION 2001;21 (10):903-10.

[93] Yao Y, Xu F, Chen M, Xu Z, Zhu Z. Adsorption behavior of methylene blue on carbon nanotubes. Bioresource Technology 2010;101(9):3040-6.

[94] Vadivelan V, Kumar KV. Equilibrium, kinetics, mechanism, and process design for the sorption of methylene blue onto rice husk. Journal of Colloid and Interface Science 2005;286(1):90-100.

[95] Kumar KV, Porkodi K. Mass transfer, kinetics and equilibrium studies for the biosorption of methylene blue using Paspalum notatum. Journal of Hazardous Materials 2007;146(1):214-26.

[96] Banerjee S, Dastidar MG. Use of jute processing wastes for treatment of wastewater contaminated with dye and other organics. Bioresource Technology 2005;96 (17):1919-28.
[97] Annadurai G, Juang R-S, Lee D-J. Use of cellulose-based wastes for adsorption of dyes from aqueous solutions. Journal of Hazardous Materials 2002;92(3):263-74.

[98] Wang S, Boyjoo Y, Choueib A. A comparative study of dye removal using fly ash treated by different methods. Chemosphere 2005;60(10):1401-7.

[99] Woolard CD, Strong J, Erasmus CR. Evaluation of the use of modified coal ash as a potential sorbent for organic waste streams. Applied Geochemistry 2002;17 (8):1159-64.

[100]Gürses A, Karaca S, Doğar Ç, Bayrak R, Açıkyıldız M, Yalçın M. Determination of adsorptive properties of clay/water system: methylene blue sorption. Journal of Colloid and Interface Science 2004;269(2):310-4. 